\title{
Characterization of bovine early growth response factor-1 and its gonadotropin-dependent regulation in ovarian follicles prior to ovulation
}

\author{
Khampoune Sayasith, Kristy A Brown, Jacques G Lussier, Monique Doré ${ }^{\text {and Jean Sirois }}$ \\ Centre de recherche en reproduction animale et Département de biomédecine vétérinaire, Faculté de médecine vétérinaire, Université de Montréal, CP 5000 , Saint-Hyacinthe, \\ Québec, Canada J2S 7C6 \\ 1Département de pathologie et microbiologie, Faculté de médecine vétérinaire, Université de Montréal, Saint-Hyacinthe, Québec, Canada J2S 7C6 \\ (Requests for offprints should be addressed to K Sayasith; Email: k.sayasith @ umontreal.ca)
}

\begin{abstract}
Early growth response factor-1 (EGR-1) is a transcription factor that is involved in the transactivation of several genes. The objective of this study was to characterize gonadotropin-dependent regulation of bovine EGR-1 in preovulatory follicles prior to ovulation. Bovine EGR-1 cDNA was obtained by RT-PCR, $5^{\prime}$ - and $3^{\prime}$-RACE, its open reading frame composed of $1623 \mathrm{bp}$, and its coding region encodes a 540-amino acid protein that displays $62-93 \%$ identity to known mammalian homologs. The regulation of EGR-1 mRNA was studied in bovine preovulatory follicles which were isolated $0-24 \mathrm{~h}$ post-hCG using semiquantitative RT-PCR/Southern blot. Results revealed that the levels of EGR-1 mRNA were very low in follicles at $0 \mathrm{~h}$, markedly increased at $6 \mathrm{~h}(P<0.05)$ when compared to $0 \mathrm{~h}$, and decreased between 12 and $24 \mathrm{~h}$ post-hCG. High levels of the EGR-1 mRNA were also observed in corpus luteum, uterus, kidney, pituitary, and spleen, moderate and low in other bovine tissues tested. Analyses performed on isolated preparations of granulosa and theca cells indicated that EGR-1 mRNA was regulated in both cell types, with a predominant expression in granulosa cells. Immunohistochemistry on sections of preovulatory follicles isolated before and after hCG confirmed its protein expression in granulosa cells, $24 \mathrm{~h}$ post-hCG. Studies of EGR-1 regulation in primary granulosa cells cultured with forskolin showed that levels of EGR-1 mRNA were low at $0 \mathrm{~h}$, highly increased at $6 \mathrm{~h}$ post-forskolin $(P<0 \cdot 05)$, and declined to steady state thereafter. Immunoblotting confirmed forskolin-induced EGR-1 protein in cultures. Interestingly, overexpression of EGR-1 increased the levels of mRNA for prostaglandin (PG) G/H synthase-2 (PGHS-2), PG E synthase (PGES), PG E2 receptor (EP2), LH receptor (LH$\mathrm{R}$ ), but not for cytochrome P450-side chain cleavage (P450scc), and cytochrome P450 aromatase (P450arom) in granulosa cultures. Thus, this study reports for the first time, a gonadotropin-dependent induction of follicular EGR-1 prior to ovulation in large monoovulatory species and its stimulating effect on the expression of genes known to be involved in prostaglandin biosynthesis pathway, thereby suggesting its potential involvement in the regulation of preovulatory events in cattle.
\end{abstract}

Journal of Molecular Endocrinology (2006) 37, 239-250

\section{Introduction}

Early growth response factor-1 (EGR-1), also known as KROX24, NGFI-A, TIS8, and ZIF268, is an inducible transcription factor that belongs to a family of immediate early response genes (Milbrandt 1987, Cao et al. 1990). Human EGR-1 is a nuclear phosphoprotein of 533 amino acids which contains domains for gene transactivation (residues 1-281) and repression (residues 281-314); a nuclear localization signal (residues 315-330); and three highly conserved zinc finger motifs (residues 332-416) responsible for the binding of EGR-1 to the promoter of several genes (Gashler \& Sukhatme 1995). The expression of EGR-1 is rapidly and transiently induced in many cell types by stimuli, including mitogens, growth factors, cytokines, and hormones, or by changes in local cellular environment, such as hypoxia and DNA-damaging agents (Gashler \& Sukhatme 1995, Yan et al. 1999). The physiological role of EGR-1 has been ascribed to diverse cellular functions, including proliferation, differentiation, apoptosis, and gene regulation (Gashler \& Sukhatme 1995, Halvorson et al. 1998, Thiel \& Cibelli 2002, Cheng et al. 2004, Giri et al. 2005, Goldhar et al. 2005, Leung-Theung-Long et al. 2005). Indeed, EGR-1 expression is significantly elevated in prostate cancer tissue and its blockage inhibits prostate tumor development (Eid et al. 1998, Baron et al. 2003). In contrast, EGR-1 expression is markedly downregulated in other cancer tissues and its overexpression

DOI: $10.1677 /$ jme.1.02078 Online version via http://www.endocrinology-journals.org 
suppresses growth and tumorigenicity in several tumor cell types (Huang et al. 1994, Liu et al. 1996). EGR-1 can modulate gene expression by binding to a GC-rich DNA consensus sequence. Furthermore, several genes involved in reproduction, including luteinizing hormone beta (LH $\beta$ ), LH receptor (LH-R) and PGES are upregulated by EGR-1 (Halvorson et al. 1998, Topilko et al. 1998, Kaiser et al. 2000, Call \& Wolfe 2002, Naraba et al. 2002, Subbaramaiah et al. 2004). The role of EGR-1 in reproduction was further underscored in genetic studies, showing that mice deficient for EGR-1 are infertile (Lee et al. 1996, Topilko et al. 1998).

Ovulation is a complex process that ultimately leads to the rupture of the follicle and release of the oocyte after the preovulatory LH surge (Armstrong 1981, Murdoch et al. 1993, Sirois et al. 2004). This process has been characterized as an acute inflammatory reaction (Espey 1980), in which the expression of several genes is stimulated (for reviews, see Richards et al. 2002, Sirois et al. 2004). The characterization of EGR-1 during the ovulatory process is of interest because of its obligatory role in reproduction, its induction in rat granulosa cells of ovulating follicles after the LH surge (Espey et al. 2000), and its ability to regulate the expression of many genes. However, these studies of EGR-1 have been limited to rodents, whereas there have been no studies describing the ovarian regulation of EGR1 in large monoovulatory species, nor is there evidence that EGR-1-regulated genes are involved in the ovulatory process. Therefore, the objective of this study was to characterize the gonadotropindependent regulation of EGR-1 in bovine preovulatory follicles prior to ovulation and to investigate the effect of EGR-1 on the expression of genes known to be involved in ovulation.

\section{Materials and methods}

\section{Cloning of bovine EGR-1 cDNA}

To clone the bovine EGR-1 cDNA, RT-PCR, $3^{\prime}$ - and $5^{\prime}$ RACE reactions were used. RT-PCR was performed using total RNA extracts (100 ng) isolated from preovulatory follicles (Sirois 1994), primers 1 (sense) and 2 (antisense), and the OneStep RT-PCR kit (Qiagen) as directed by the manufacturer (Fig. 1A $a$ ) . These primers were designed from highly conserved coding regions of mouse (GenBank accession number: NM_007913) and human (GenBank accession number: NM_001964) EGR-1 homologs (Fig. 1B). RT-PCR products were subcloned into pGEM-T Easy vector and sequenced (Service de séquençage, Université Laval, Québec, Canada). A large bovine EGR-1 cDNA fragment of 1517-bp was obtained (Fig. 1A $a$ ).
To characterize the $3^{\prime}$-end of the bovine EGR-1 cDNA, 3'-RACE was undertaken with RNA extracts $(5 \mu \mathrm{g})$ prepared from a preovulatory follicle obtained $24 \mathrm{~h}$ post-hCG, in accordance with the manufacturer's instructions (Invitrogen Life Technologies). Reverse transcription was performed with a poly-dT oligonucleotide with anchor sequences at its $5^{\prime}$-end (primer 3), followed by a first PCR done with sense primer 4 and antisense primer 5 , and a second nested PCR with sense primer 6 and antisense primer 7 (Fig. 1A $b$ ). Primers 4 and 6 were designed from the $3^{\prime}$-end of a bovine EGR-1 cDNA fragment.

To obtain the $5^{\prime}$-missing end of bovine EGR-1 cDNA, $5^{\prime}$-RACE was performed with the $5^{\prime}$-RACE system version $2 \cdot 0$, in accordance with the manufacturer's instructions (Invitrogen Life Technologies). Briefly, reverse transcription was carried out as directed using

A

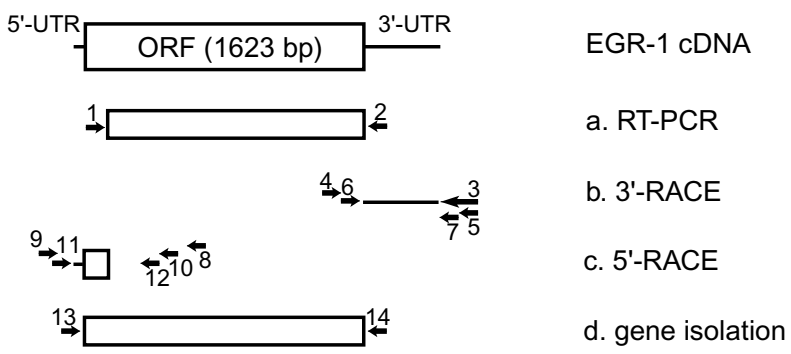

B

1. 5'-AGGAGATGATGCTGAGCAACG-3'

2. 5'-TTAGCAAATTTCAATTGTCCTGG-3'

3. 5'-GTACCGGATCCTCTAGAGAGCTCGTCGACCTCGA GGAATCAAGCTTTTTTTTTTTTTTTTT-3'

4. 5'-CCAGCTACTACCTCTTATCCATCCC-3'

5. 5'-GTCGACCTCGAGGAATTCAAGCTT-3'

6. 5'-CCTCAGCTGTCACCAACTCCTTCAGC-3'

7. 5'-GTACCGGATCCTCTAGAGAGCTC-3'

8. 5'-AAGATGTCAGTGTTAGGTGTG-3'

9. 5'-GGCCACGCGTCGACTAGTACGGGGGGGGGG-3'

10. 5'-GGAGATGATGCTGAAGATGAGGGGT-3'

11. 5'-CTACTACTACTATAGGCCACGCGTCGACTAGTAC-3'

12. 5'-AGAGAGATGTCAGGAAAGGACTCTGC-3'

13. 5'-GTGGAATTCGCCGCCAGGATGGCCGCGG CCAAGGCCCAA-3'

14. 5'-ACCTCTAGATTAGCAAATTTCAATTGTCCT GG-3'

Figure 1 Cloning strategy for isolating the bovine EGR-1 cDNA. (A) The open reading frame (ORF) is represented as an open box. A solid line indicates the $3^{\prime}$ - and $5^{\prime}$-untranslated regions (UTR). Numbers in parenthesis indicate the size in base pairs of EGR-1 cDNA. Bovine EGR-1 was characterized by a combination of RT-PCR (a), 3'-RACE (b) and 5'-RACE (c), and the complete coding region was isolated by RT-PCR (Fig. 1Ad), as described in Materials and methods. Arrows and numbers indicate the orientation, relative position, and identity of each oligonucleotide used in each cloning step. (B) List of oligonucleotides used in section $\mathrm{A}$. 
antisense primer 8 (Fig. 1Ac) and $5 \mu \mathrm{g}$ of RNA extracted from a preovulatory follicle obtained $24 \mathrm{~h}$ post-hCG. The first PCR was performed with sense abridged anchor primer 9 (Invitrogen Life Technologies) and antisense primer 10, and the second PCR was done with sense abridged universal amplification primer 11 (Invitrogen Life Technologies) and antisense primer 12 (Fig. 1Ac). Primers 8, 10, and 12 were designed from the $5^{\prime}$-end of a bovine EGR-1 cDNA fragment. PCR consisted of 35 cycles of $94^{\circ} \mathrm{C}$ for $30 \mathrm{~s}, 58^{\circ} \mathrm{C}$ for $1 \mathrm{~min}$, and $72{ }^{\circ} \mathrm{C}$ for $1 \mathrm{~min}$, and PCR products were subcloned into pGEM-T Easy vector and sequenced. The complete bovine EGR-1 coding region was isolated by RT-PCR using $100 \mathrm{ng}$ RNA from $24 \mathrm{~h}$ post-hCG preovulatory follicle, sense primer 13 and antisense primer 14 (Fig. 1Ad), and sequenced.

\section{In vivo model of ovulation}

Holstein heifers of 2-3 years of age, exhibiting normal estrous cycles were used as a model of hCG-induced ovulation to study the regulation of EGR-1 during the ovulatory process in vivo, as previously described (Sirois 1994). Briefly, bovine preovulatory follicles were obtained after induction of luteolysis on day 7 of the estrous cycle and i.v. administration of an ovulatory dose of hCG (3000 IU). The ovary bearing the preovulatory follicle was isolated by ovariectomy (via colpotomy) from individual heifers at $0-26 \mathrm{~h}$ after hCG (Sirois 1994). The interval of time from hCG administration to ovulation is $26-28 \mathrm{~h}$ in this animal model. The preovulatory follicles were dissected from the ovary with a scalpel and pieces of follicle wall (i.e. theca interna with attached granulosa cells) were prepared and further dissected into isolated preparations of granulosa and theca cells (Sirois 1994). All tissue samples were stored at $-70{ }^{\circ} \mathrm{C}$. All animal procedures were approved by the Institutional Animal Care and Use Committee of the Universite de Montréal and were consistent with the guidelines of the Canadian Council of Animal Care.

\section{RNA extraction and semiquantitative RT-PCR/Southern blot}

All tissues were obtained from a slaughterhouse, and total RNA was isolated from bovine preovulatory follicles, granulosa cell cultures, and tissues using the TRIzol reagent, and a Kinematica PT 1200C Polytron Homogenizer (Fisher Scientific, Montréal, Canada), according to the manufacturer's instructions. RT-PCR/Southern blot was performed using extracts (100 ng), the OneStep RT-PCR kit as directed by the supplier, sense (5'-CCG ACT ATC TGT TTC CAC AAC$\left.3^{\prime}\right)$ and antisense $\left(5^{\prime}\right.$-TTA GCA AAT TTC AAT TGT
CCT GG-3') primers specific for bovine EGR-1 gene, producing a 871-bp DNA fragment, and sense $\left(5^{\prime}\right.$-GTT TCC AGT AGA TTC CAC CC-3 $\left.{ }^{\prime}\right)$ and antisense ( $5^{\prime}$-TCC ACC ACC CTG TTG CTG TA-3 ${ }^{\prime}$ ) primers specific for bovine GAPDH, generating a 850-bp DNA fragment (Tsai et al. 1996). The reaction conditions were one cycle of $50{ }^{\circ} \mathrm{C}$ for $30 \mathrm{~min}$ and $95^{\circ} \mathrm{C}$ for $15 \mathrm{~min}$, followed by 19 cycles for EGR-1 or 13 cycles for GAPDH of $94^{\circ} \mathrm{C}$ for $30 \mathrm{~s}, 59{ }^{\circ} \mathrm{C}$ for $1 \mathrm{~min}$, and $72^{\circ} \mathrm{C}$ for $2 \mathrm{~min}$. The number of cycles used was optimized for each gene to fall within the linear range of PCR amplification. PCR products were resolved on 2\% Tris-acetate/EDTAagarose gels, transferred to nylon membrane, and hybridized with corresponding ${ }^{32}$ P-labeled EGR-1 and GAPDH cDNA fragments using QuikHyb hybridization solution (Stratagene, LaJolla, CA). Membranes were exposed to X-OMAT Kodak films with the intensifier screen and signals were quantified by densitometer using the ImageQuant software.

\section{Immunohistochemical localization of EGR-1 protein in bovine follicles}

Immunohistochemistry was performed as previously described (Brûlé et al. 2003). Briefly, formalin-fixed tissues were paraffin-embedded and $3 \mu$ m-thick sections were prepared. The paraffin was removed by passage through graded xylene and alcohol solutions and sections were rehydrated, rinsed with TBS $(150 \mathrm{mM}$ $\mathrm{NaCl}, 0 \cdot 1 \mathrm{M}$ Tris, $\mathrm{pH} 7 \cdot 5$ ), and incubated for $10 \mathrm{~min}$ in TBS containing $0 \cdot 1 \mathrm{M}$ glycine. After the incubation, sections were heated in a pressure cooker for $14 \mathrm{~min}$, incubated in blocking buffer containing TBS, $1 \%$ BSA, and $1 \%$ fat-free skim milk, and then incubated overnight at $4{ }^{\circ} \mathrm{C}$ with a rabbit polyclonal antibody against human EGR-1 (1:10 dilution; Santa Cruz Biotechnologies). The specificity of the antibody against bovine protein was verified by immunoblotting using extracts prepared from granulosa cells overexpressing bovine EGR-1 (data not shown). After three $5 \mathrm{~min}$ rinses with TBS, sections were incubated for $2 \mathrm{~h}$ at room temperature with a monoclonal anti-rabbit IgG conjugated to alkaline phosphatase (1:200 dilution; Sigma). After three washes in TBS, the reaction was revealed using the NBT/BCIP alkaline phosphatase substrate (Roche), and sections were mounted.

\section{EGR-1 expression construct, granulosa cell cultures, and DNA transfection}

To generate the EGR-1 expression construct, the fulllength bovine EGR-1 was isolated by RT-PCR using RNA extracts (100 ng) of a preovulatory follicle, sense primer 13, and antisense primer 14. RT-PCR consisted of one cycle of $50{ }^{\circ} \mathrm{C}$ for $30 \mathrm{~min}$ and $95{ }^{\circ} \mathrm{C}$ for $15 \mathrm{~min}$ 
followed by 35 cycles of $94^{\circ} \mathrm{C}$ for $30 \mathrm{~s}, 59^{\circ} \mathrm{C}$ for $1 \mathrm{~min}$, and $72{ }^{\circ} \mathrm{C}$ for $2 \mathrm{~min}$. Reaction products were subcloned into the expression vector pcDNA 3.1 (+) (Invitrogen Life Technologies) and sequenced.

Granulosa cell cultures were prepared as previously described (Liu et al. 1999, Sayasith et al. 2004). Briefly, pairs of bovine ovaries bearing a newly formed corpora lutea and a follicle of 8-12 $\mathrm{mm}$ in diameter (dominant follicle of the first wave of the estrous cycle) were obtained from a slaughterhouse. Granulosa cells were isolated from the largest follicle as previously described (Liu et al. 1997), seeded at a density of $2 \times 10^{6}$ in the $100 \mathrm{~mm}$ Petri dish containing $10 \mathrm{ml}$ of minimal essential medium (MEM; Invitrogen Life Technologies) supplemented with L-glutamine, non-essential amino acids, $2 \%$ fetal bovine serum, insulin $(1 \mu \mathrm{g} / \mathrm{ml})$, transferrin $(5 \mu \mathrm{g} / \mathrm{ml})$, and penicillin (100 units $/ \mathrm{ml})$ streptomycin $(100 \mu \mathrm{g} / \mathrm{ml})$, and incubated at $37^{\circ} \mathrm{C}$ in a humidified atmosphere of $5 \% \mathrm{CO}_{2}$. To study the regulation of EGR-1 in vitro, cells were serum-starved overnight in fresh MEM and incubated with forskolin $(10 \mu \mathrm{M}$; Calbiochem) for various times. After incubation, the cells were harvested and RNA and protein extracts were isolated. To examine the effect of EGR-1 on the transcript expression of other genes, serumstarved granulosa cells were transfected with the EGR-1 expression vector $(4 \mu \mathrm{g} /$ Petri dish) in serum-free MEM using LipofectAMINE PLUS, in accordance with the manufacturer's protocol (Invitrogen Life Technologies). Three hours after transfection, cells were rinsed and incubated in serum-free MEM in the absence or presence of forskolin $(10 \mu \mathrm{M})$ for $24 \mathrm{~h}$, and the RNA extraction and RT-PCR analyses were performed.

\section{RT-PCR analysis}

RNA extracts (100 ng) isolated from granulosa cells were analyzed by RT-PCR to study the expression of EGR-1, PGHS-2, PGES, EP2, P450scc, P450arom, and LH-R using the OneStep RT-PCR kit and various primers: 5'-CAC AGT GCA CTA CAT ACT TAC C-3' (sense) and $5^{\prime}$-GTC TGG AAC AAC TGC TCA TCG C-3' (antisense) primers, generating a 735-bp fragment of PGHS-2; 5'-TGA TGA ACG GCG AGG TGC TC-3' (sense) and 5'-ATG CCA CGG TGT GTA CCA TAC GG-3' (antisense) primers, generating a 330-bp fragment of PGES; $5^{\prime}$-CTG CTG GAT CAT TGG AAG TAT GC-3' (sense) and 5'-TCC ATC TCG CTG TTC CAC GTG-3' (antisense) primers, generating a 439-bp fragment of EP2; 5'-AGA GAA TGG ACT TTC GCC ACA TC-3' (sense) and $5^{\prime}$-AGG GAC ACT GGT GTG GAA CAT C-3' (antisense) primers, generating a 525-bp fragment of P450scc; $5^{\prime}$-CAC ATC CTC AAT ACC AGG TCC C-3' (sense) and 5'-AGA GGT GTC CAG CAT GAT GCG-3' (antisense) primers, generating a 469-bp fragment of P450arom; and 5'-CTT CTG CAT GGG GCT CTA-3' (sense) and $5^{\prime}$-TCA CGT TGC GAA TCA GGA TGG-3' (antisense) primers, generating a 395-bp fragment of LH-R. Each reaction was performed at one cycle of $50{ }^{\circ} \mathrm{C}$ for $30 \mathrm{~min}$ and $95^{\circ} \mathrm{C}$ for $15 \mathrm{~min}$ followed by 35 cycles of $94^{\circ} \mathrm{C}$ for $30 \mathrm{~s}, 59^{\circ} \mathrm{C}$ for $1 \mathrm{~min}$, and $72^{\circ} \mathrm{C}$ for $2 \mathrm{~min}$. PCR products were electrophoresed on $2 \%$ Tris-acetate/EDTA-agarose gels.

\section{Cell extracts and immunoblot analysis}

Cell extracts were prepared from granulosa cell cultures as described previously (Sayasith et al. 2004), and protein concentrations were determined by the method of Bradford (Bradford 1976) (Bio-Rad Protein Assay). Samples $(100 \mu \mathrm{g} /$ well $)$ were resolved by one-dimensional SDS-PAGE and electrophoretically transferred to PVDF membranes (Amersham Pharmacia Biotech). Membranes were incubated with a rabbit polyclonal antibody against human EGR-1 (1:200 dilution), and immunoreactive proteins were visualized by incubation with the horseradish peroxidase-linked donkey antirabbit secondary antibody (1:6000 dilution) and the enhanced chemiluminescence system (ECL plus) according to the manufacturer's protocol (Amersham Pharmacia Biotech).

\section{Statistical analyses}

One-way ANOVA was used to test the effect of different times of hCG on levels of EGR-1 mRNA in samples. EGR-1 mRNA levels were normalized with the control gene GAPDH prior to analysis. Statistical analyses were performed using JMP software (SAS Institute, Inc., Carry, NC). When ANOVA indicated a significant $\mathrm{F}$ value $(P<0 \cdot 05)$, Dunnett's test was used for multiple comparisons of individual means.

\section{Results}

\section{Characterization of the bovine EGR-1 cDNA}

The bovine EGR-1 cDNA was cloned by a combination of RT-PCR, $3^{\prime}$ - and $5^{\prime}$-RACE using RNA extracts isolated from preovulatory follicles $24 \mathrm{~h}$ after hCG treatment (Sirois 1994) and primers designed from highly conserved coding regions of mouse and human EGR-1 homologs. Results showed that full-length bovine EGR-1 cDNA contains an ORF of 1623 bp (including stop codon), a $5^{\prime}$-untranslated region (UTR) of $5 \mathrm{bp}$, and a $3^{\prime}$-UTR of $529 \mathrm{bp}$. The nucleotide sequence of bovine EGR-1 was submitted to GenBank with accession number AY924307 and its predicted complete coding region was isolated by RT-PCR, subcloned and confirmed by sequencing. This coding region encodes 
a 540-amino acid protein that is three amino acid residues shorter than human EGR-1, and 7, 32, 30, and 25 amino acid residues longer than mouse, rat (GenBank accession number: NM_012551), chicken (GenBank accession number: AY034140) and fish (GenBank accession number: XM_688016) homologs respectively (Fig. 2). Comparative analyses indicated that bovine EGR-1 amino acid sequence is relatively similar to human $(93 \%)$, mouse $(89 \%)$, rat $(84 \%)$, chicken $(73 \%)$, and fish (62\%) homologs, and contains conserved structural domains putatively involved in its functions, including three zinc-finger motifs responsible for the binding with the promoter of genes, a transactivation domain, a glycine-rich region, two serine-rich regions, a nuclear localization signal, and an inhibitory domain (Fig. 2).

\section{Tissue expression of bovine EGR-1 mRNA and its gonadotropin-dependent regulation in bovine follicles prior to ovulation}

To examine the expression of bovine EGR-1 mRNA in various tissues, RT-PCR/Southern blot was performed using RNA extracts isolated from bovine tissues. Results showed that levels of EGR-1 mRNA were high to very high in corpora lutea, uterus, kidney, pituitary, spleen, and preovulatory follicle, and moderate to low in other tissues (Fig. 3A), whereas levels of GAPDH mRNA (control gene) remained relatively constant in tissues tested (Fig. 3B). To study the regulation of EGR-1 mRNA in bovine follicles prior to ovulation, semiquantitative RT-PCR/Southern blot was performed using RNA extracts obtained from the wall of preovulatory follicles isolated at $0,6,12,18$, and $24 \mathrm{~h}$ after hCG treatment. Representative results revealed that levels of EGR-1 mRNA were very low at $0 \mathrm{~h}$, increased at $6 \mathrm{~h}$, and decreased from 12 to $24 \mathrm{~h}$ post-hCG (Fig. 3C). Results from several follicles expressed as ratios of EGR-1 to GAPDH showed a significant increase of EGR-1 mRNA at $6 \mathrm{~h}$ post-hCG when compared to $0 \mathrm{~h}(P<0 \cdot 05$; Fig. 3D).

\section{Localization of EGR-1 mRNA and protein in preovu- latory follicles prior to ovulation}

To investigate cellular localization of bovine EGR-1 mRNA expression in preovulatory follicles, RT-PCR/Southern blot was performed using RNA preparations of isolated granulosa and theca cells prepared from preovulatory follicles obtained at 0,6 , $12,18,20,22$, and $24 \mathrm{~h}$ post-hCG. In granulosa cells, representative results indicated that levels of EGR-1 transcript were very low at $0 \mathrm{~h}$, increased at $6 \mathrm{~h}$ after hCG, and decreased thereafter (Fig. 4A). When results from several follicles were expressed as EGR-1 and GAPDH ratios, a high increase of EGR-1 was observed at

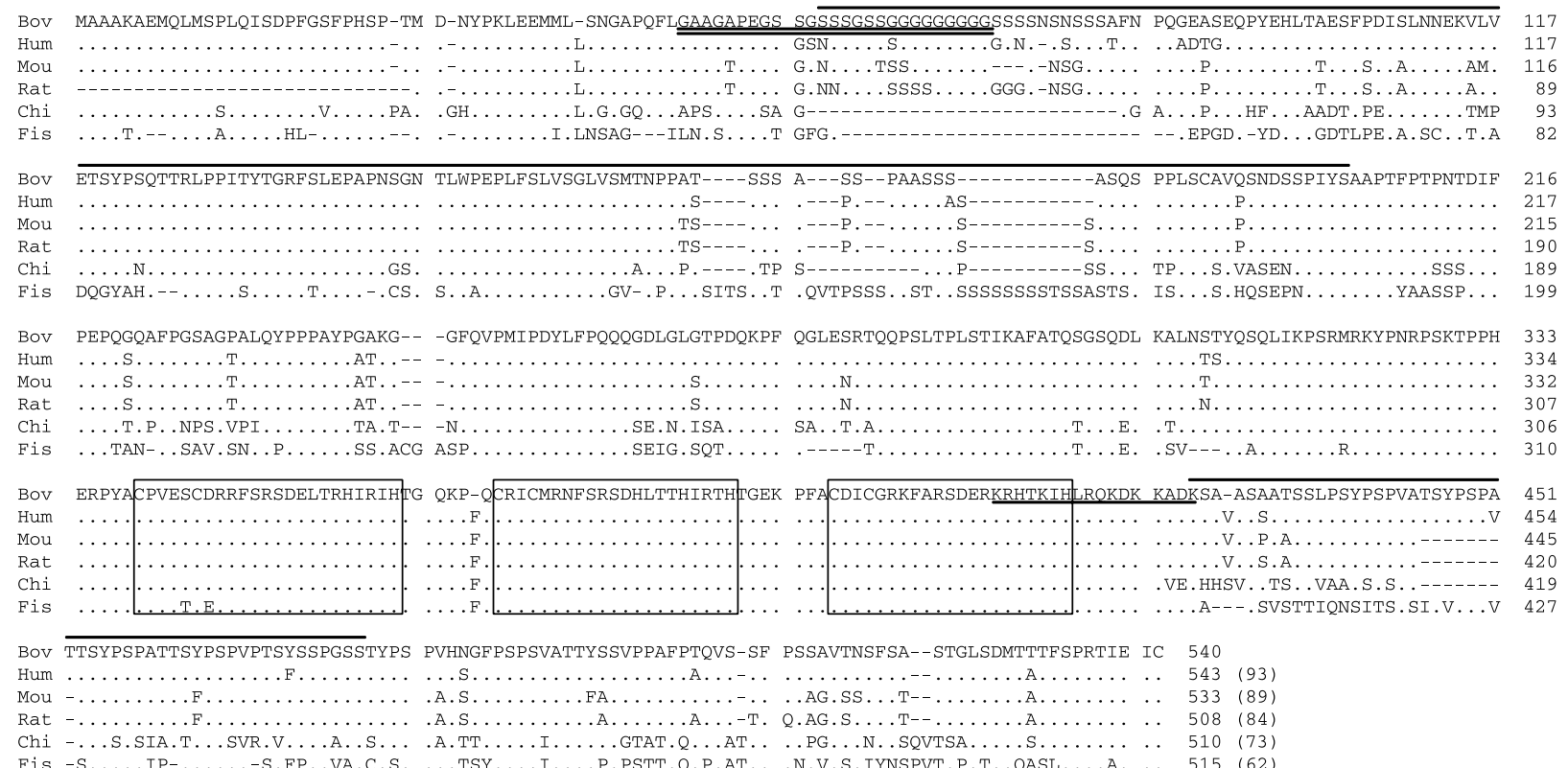

Figure 2 Deduced amino acid sequences of bovine EGR-1 and its comparison with other mammalian homologs. The amino acid sequence of bovine EGR-1 (Bov) is aligned with human (Hum), mouse (Mou), rat, chicken (Chi), and fish (Fis) homologs. Identical residues are indicated by a printed period. Hyphens indicate gaps in protein sequence, created by optimized alignment. Numbers on the right refer to the last amino acid on that line. The percentage in parentheses refers to the degree of identity in amino acid residues when comparisons are done with bovine EGR-1. Box regions include three zinc finger domains. A glycine-rich region is double underlined. Two serine-rich regions are overlined. A nuclear localization signal is underlined. 

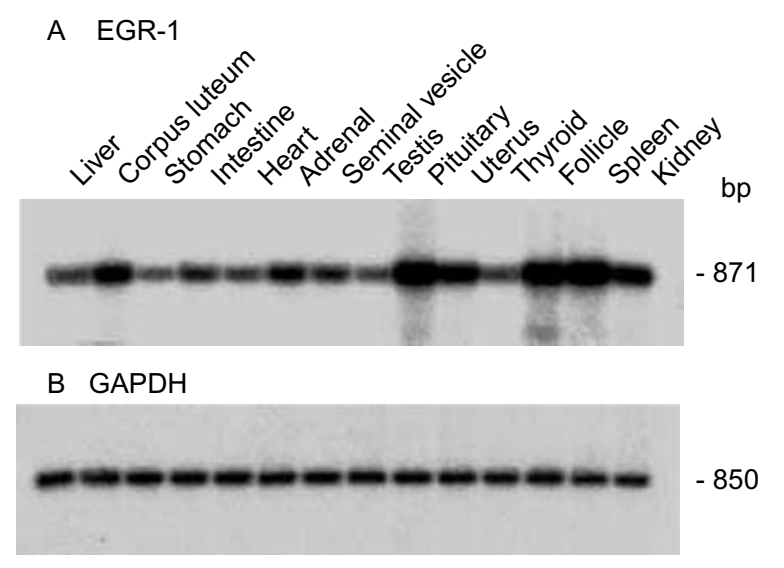

C
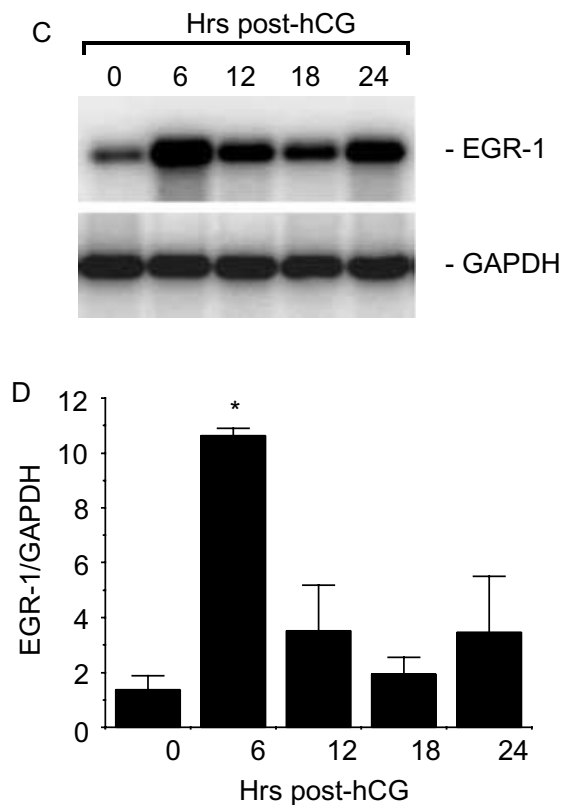

Figure 3 Expression of EGR-1 mRNA in bovine tissues and its gonadotropin-dependent regulation in preovulatory follicles. Total RNA were extracted from various tissues, and samples (100 ng) were analyzed by a semiquantitative RT-PCR/Southern blot for the content of bovine EGR-1 (A) and GAPDH (B) mRNA, as described in Materials and methods. For studies of EGR-1 regulation in follicles, RNA extracts were prepared from bovine preovulatory follicles obtained $0,6,12,18$, and $24 \mathrm{~h}$ after hCG treatment, and samples (100 ng) were analyzed by a semiquantitative RT-PCR/Southern blot. (C) Representative results of EGR-1 and GAPDH mRNA levels are presented from one follicle per time point. (D) The EGR-1 signal was normalized with the control gene GAPDH, and results are presented as ratios of EGR1 to GAPDH. Mean \pm S.E.M.; $n=4$ distinct follicles (each from a different animal) per time point; except $n=2$ at $6 \mathrm{~h}$ post-hCG. Bars marked with an asterisk are significantly different from $0 \mathrm{~h}$ posthCG $(P<0.05)$. Numbers on the right of panels, $A$ and $B$ indicate the size of the PCR fragment.

$6 \mathrm{~h}$ post-hCG when compared to $0 \mathrm{~h}(P<0 \cdot 05$; Fig. 4B). In theca cells, representative results showed that levels of EGR-1 mRNA were low at $0 \mathrm{~h}$, increased at $6 \mathrm{~h}$, and decreased between 12 and $24 \mathrm{~h}$ post-hCG (Fig. 4C).
Results from several follicles expressed as ratios of EGR-1 to GAPDH revealed a significant increase of transcripts at $6 \mathrm{~h}$ post-hCG when compared to $0 \mathrm{~h}(P<0.05$; Fig. 4D). Interestingly, the induction of EGR-1 mRNA predominantly occurred in granulosa cells.

To determine if the induction of EGR-1 mRNA was associated with its protein induction in preovulatory follicles, immunohistochemistry was undertaken with sections of bovine follicles isolated before and after hCG. Results revealed that the EGR-1 protein immunoreactivity was very low or undetectable in follicles obtained at $0 \mathrm{~h}$ (Fig. 5A), in keeping with very low levels of EGR-1 mRNA detected in preovulatory follicles obtained at this time, but markedly increased in granulosa cells of a follicle isolated at $24 \mathrm{~h}$ post-hCG (Fig. 5B and C). As control of immunohistochemical reaction, no immunostaining was observed when the primary antibody was replaced with PBS (Fig. 5D).

\section{Regulation of EGR-1 and its effect on the expression of PGHS-2, PGES, EP2, P450arom, P450scc, and LH-R transcript in primary cultures of bovine granulosa cells}

To study the regulation of EGR-1 in vitro, granulosa cells were isolated from preovulatory follicles and cultured in the absence or presence of forskolin for various times. These primary cultures have been previously established as a valuable model to study the regulation of bovine PGHS-2 observed in vivo (Liu et al. 1999, Sayasith et al. 2004). RT-PCR/Southern blot analyses showed that levels of EGR-1 mRNA were low at $0 \mathrm{~h}$, increased at $6 \mathrm{~h}$, and declined to steady-state levels from 12 to $72 \mathrm{~h}$ post-forskolin (Fig. 6A). When results from three independent experiments were expressed as ratios of EGR-1 to GAPDH, a significant and transient increase of EGR-1 mRNA was observed at $6 \mathrm{~h}$ postforskolin when compared with $0 \mathrm{~h}(P<0 \cdot 05$; Fig. 6B). To investigate if the induction of EGR-1 mRNA was associated with its protein expression, immunoblotting was performed using extracts isolated from granulosa cells after forskolin treatment. Results revealed that the levels of EGR-1 protein were low at $0 \mathrm{~h}$, and increased from 6 to $24 \mathrm{~h}$ post-forskolin (Fig. 6C).

To investigate whether EGR-1 induction may affect levels of PGHS-2, PGES, EP2, P450arom, P450scc and LH-R mRNA, granulosa cells, either controls or those transfected with the EGR-1 expression vector, were cultured in the absence or presence of forskolin for $24 \mathrm{~h}$. In untransfected cells, results from RT-PCR analyses revealed that basal expression of EGR-1, PGHS-2, PGES, EP2, P450arom, and P450scc mRNA was low or undetectable, but markedly stimulated by forskolin (Fig. 6D, lanes 2 vs 1). In EGR-1-transfected cells, overexpression of EGR-1 increased basal expression of PGHS-2, PGES, and EP2 mRNA, initially 
A Granulosa

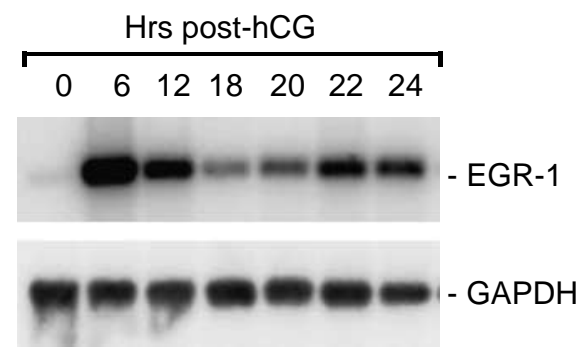

C Theca

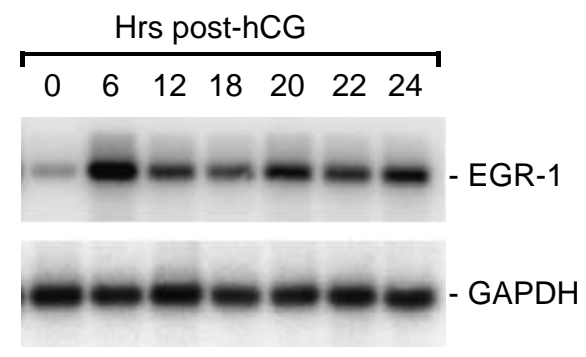

B Granulosa

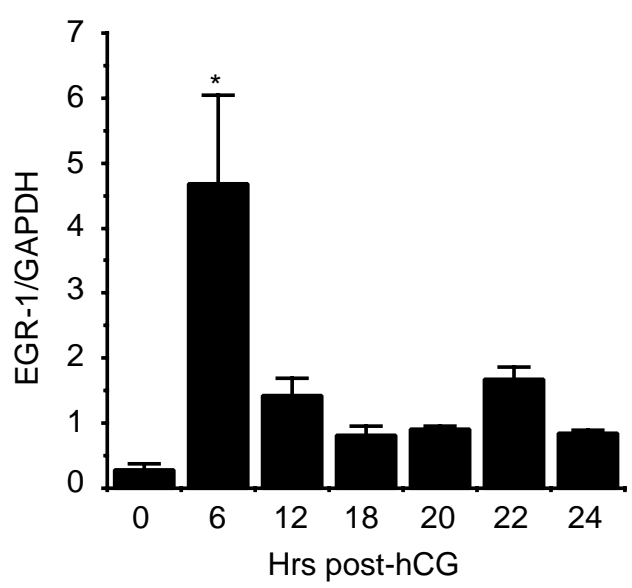

Theca

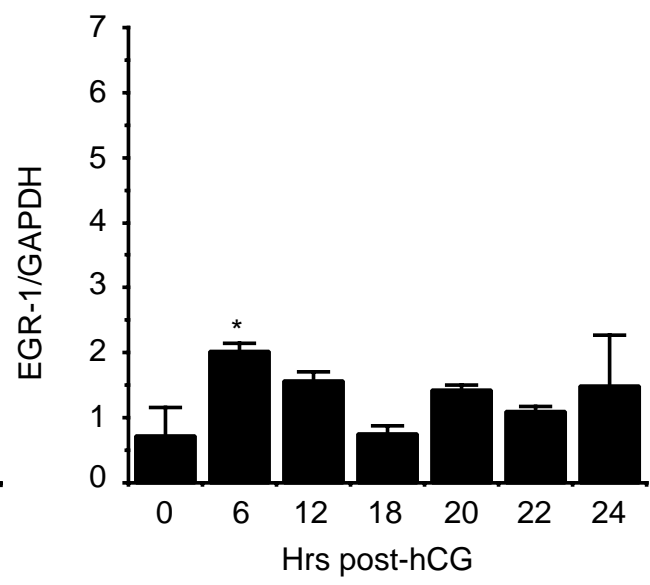

Figure 4 Localization of EGR-1 mRNA in bovine preovulatory follicles. Total RNA preparations of isolated granulosa and theca cells were obtained from bovine preovulatory follicles at various times after hCG treatment, and a semiquantitative RT-PCR/Southern blot was performed with samples (100 ng) to analyze EGR-1 and GAPDH transcripts, as described in Materials and methods. Representative results of EGR-1 and GAPDH mRNA levels are presented from one granulosa $(A)$ and one theca $(C)$ sample per time point. The signal of EGR-1 was normalized with those of the GAPDH, and results are presented as ratios of EGR-1 to GAPDH for granulosa (B) and theca (D) cells. Mean \pm S.E.M.; $n=2$ distinct follicles (each from a different animal) per time point. Bars marked with an asterisk are significantly different from $0 \mathrm{~h}$ post-hCG $(P<0 \cdot 05)$.

observed in untransfected cells (Fig. 6D, lanes 3 vs 1 ), whereas the treatment with forskolin enhanced the latter EGR-1-dependent increase (Fig. 6D, lanes 4 vs 3). Overexpression of EGR-1 in the absence or presence of forskolin had no effect on the expression of P450arom and P450scc mRNA when compared to untransfected cells (Fig. 6D, lanes 3 vs 1, and lanes 4 vs 2). Basal levels of LH-R mRNA were very low, and not affected by forskolin treatment in untransfected cells (Fig. 6D, lanes 2 vs 1 ), but highly increased by EGR-1 overexpression (Fig. 6D, lanes 3 vs 1 and 2). The latter increase was markedly stimulated by forskolin (Fig. 6D, lanes 4 vs 3 ).

\section{Discussion}

This study reports for the first time, the regulation of EGR-1 in bovine preovulatory follicles prior to ovulation. Studies on the regulation of EGR-1 in the ovulatory process are very limited, with two published reports from the rodent ovary (Espey et al. 2000, Russell et al. 2003). As there have been no reports on the regulation of EGR-1 in follicles of species with a long ovulatory process, including cows, mares, or primates, the present study is of interest to determine the importance of EGR-1 on the important physiological process in large monoovulatory species. Previous studies from rodents have indicated that the levels of EGR-1 mRNA were low before hCG treatment, but rapidly and transiently increased in granulosa cells at $4 \mathrm{~h}$ after hCG (Espey et al. 2000, Russell et al. 2003). As observed in rodents, our results also showed a high and transient increase of EGR-1 transcripts at $6 \mathrm{~h}$ after hCG in preovulatory follicles. Interestingly, this increase predominantly occurred in granulosa cells, suggesting that EGR-1 may have important functions in these cells, but the precise role of the latter remains to be determined. In addition, our findings revealed that 


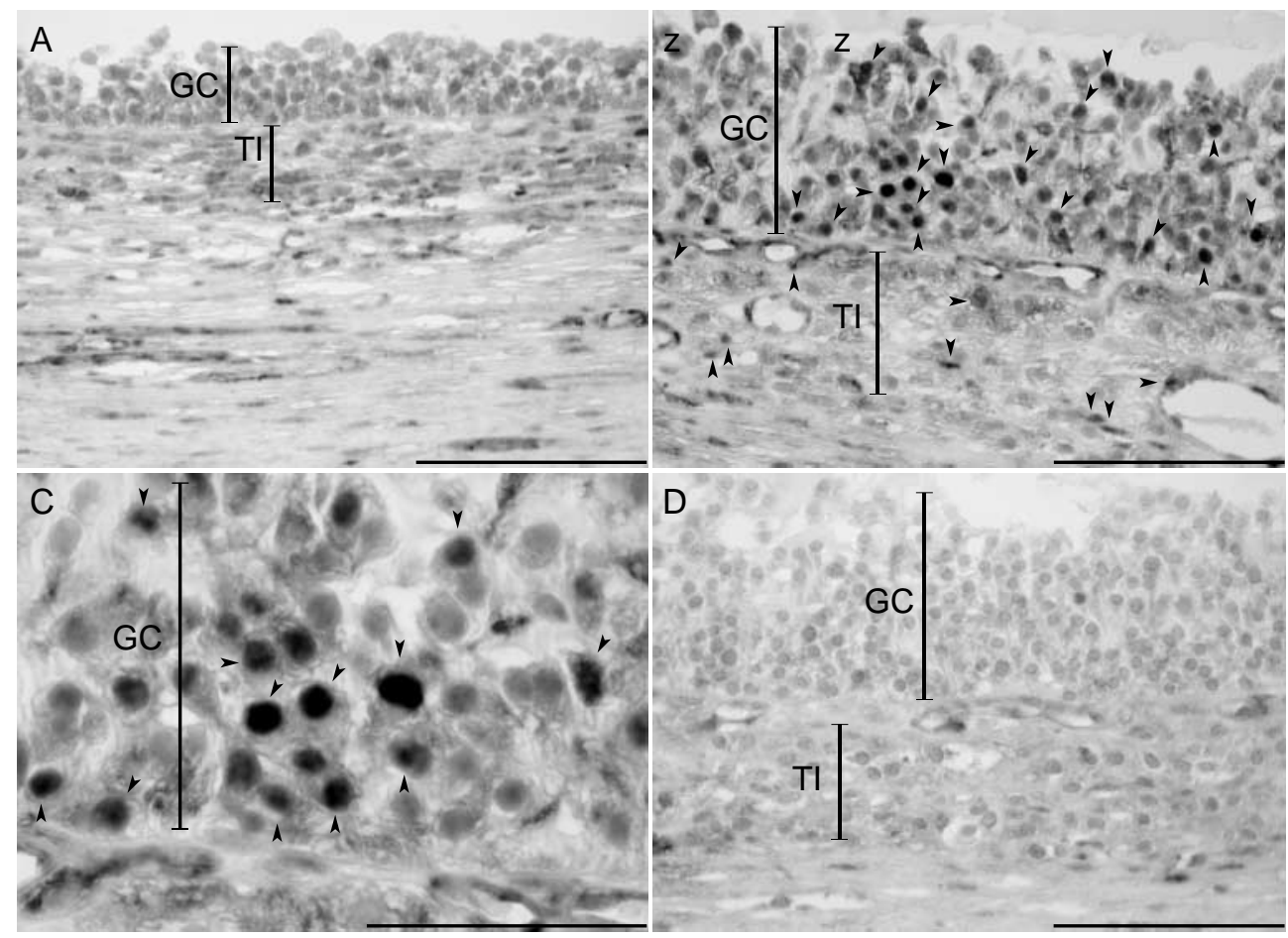

Figure 5 Immunohistochemical localization of EGR-1 protein in bovine preovulatory follicles. Immunohistochemistry was performed on formalin-fixed sections of preovulatory follicles isolated at 0 and $24 \mathrm{~h}$ after hCG treatment, as described in Materials and methods. Results show very low or no EGR-1 staining in follicles obtained at $0 \mathrm{~h}(\mathrm{~A})$, but a marked EGR-1 immunoreactivity was detected in follicles isolated at $24 \mathrm{~h}$ post-hCG; EGR-1 protein immunostaining was high in granulosa cells, but very low in theca layer ( $B$ and $C$ ). (D) Control staining from the follicular tissue presented in $B$ and $C$ was negative when the primary antibody was replaced with PBS. The limits of the granulosa cell (GC) layer are indicated. The region above the granulosa cell layer is for the antrum, whereas the region immediately beneath corresponds to thecal layers, including the limits of theca interna (TI). Arrowheads indicate positive cells. Magnification, $A, B$, and $D(\times 400$ with a scale bar equal to $0.05 \mathrm{~mm})$, and $C(\times 1000$ with a scale bar equal to $0.1 \mathrm{~mm}$ ).

high levels of EGR-1 mRNA were also observed in the pituitary, spleen, uterus, and corpora lutea, suggesting that EGR-1 may play an important role in these tissues.

Ovulation is a complex process initiated by LH stimulation, which is accompanied by an increase in the expression of several genes, including PGHS-2, PGES, an inhibitor of the cell cycle p21 ${ }^{\mathrm{CIP} 1}$, membrane type 1-metalloproteinase (MT1-MMP), MMP19, tissue inhibitor of MMP1, and cathepsin L (for reviews, see Richards et al. 2002, Sirois et al. 2004). Some of these genes contain GC-rich regions in their promoters, which are recognized as targets for EGR-1. Many studies have shown that EGR-1 can bind directly to GC boxes or act in harmony with other proteins to mediate transactivation of several genes or its own expression in different cell types. Indeed, binding of EGR-1, Sp1, and CREB transcription factors to their corresponding sites plays a key role in the regulation of cathepsin $\mathrm{L}$ in rat granulosa cells (Sriraman \& Richards 2004), whereas interactions between EGR-1, Sp1/Sp3, and NFAT (nuclear factor of activated $\mathrm{T}$ cells) $\mathrm{c} 1$ are required for the MT1-MMP expression in glomerula mesanglial cells (Alfonso-Jaume et al. 2004). In contrast, EGR-1 alone was needed for the induction of MT1MMP and $\mathrm{p}_{21}{ }^{\mathrm{CIP} 1}$ in other cell types (Haas et al. 1999, Aicher et al. 2003). It has been reported that EGR-1 acts as a key regulator of CD44 expression, a major cellsurface receptor of hyaluronan (HA) in several cell types (Maltzman et al. 1996, Abdel-Latif et al. 1999, Fitzgerald \& O'Neill 1999, Mishra et al. 2005). HA is the main component of cumulus expansion (for review, see Richards et al. 2002), and its synthesized amount is closely correlated with the degree of cumulus expansion (Chen et al. 1996). Recent studies have indicated that CD44 was expressed in the membrane of cumulus cells (Kimura et al. 2002, Yokoo et al. 2002), and identified a HA-binding protein required for expansion of the cumulus-oocyte complex (Yokoo et al. 2002). Thus, it is of interest to know whether EGR-1 is involved in CD44 expression in cumulus cells during the ovulatory process. It has also been suggested that the binding of EGR-1 to two CG-rich regions on the rat 
LH-R gene promoter plays a critical role in the expression of LH-R in a tumor cell line derived from mouse Leydig cells (Yoshino et al. 2002), while genetic disruption of EGR-1 resulted in a loss of LH-R

A

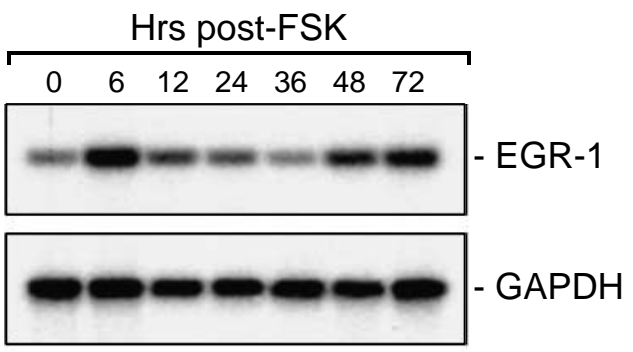

B

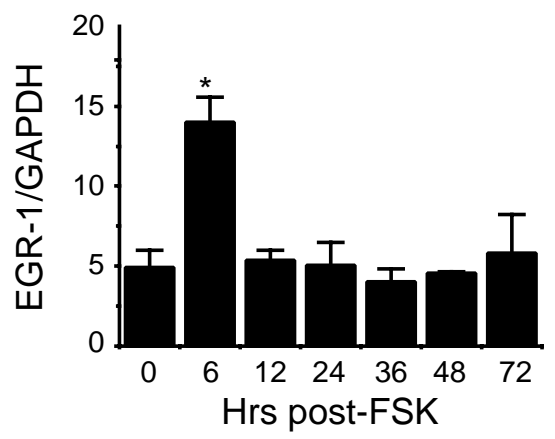

C

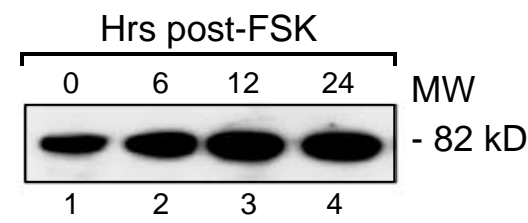

$\mathrm{D}$

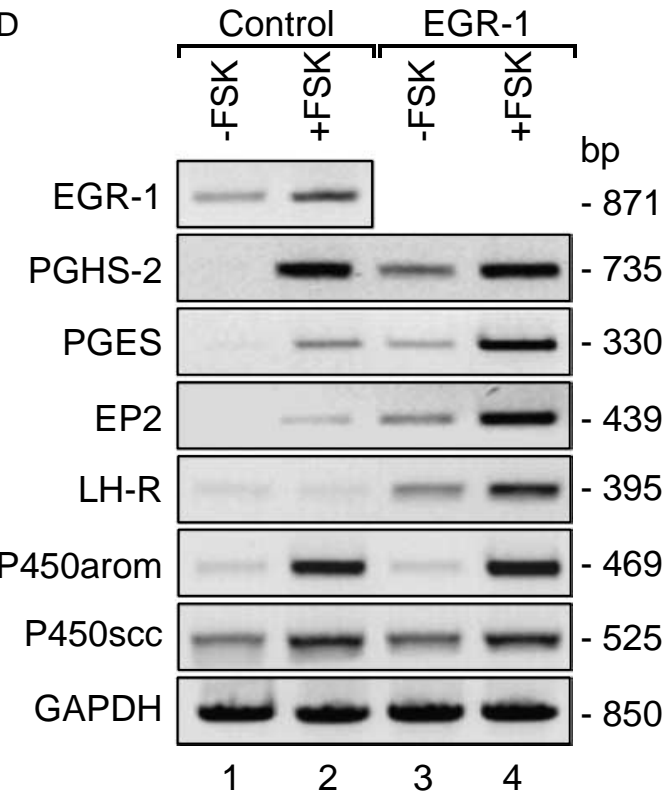

www.endocrinology-journals.org expression in ovaries and infertility of female mice, suggesting the involvement of EGR-1 in ovarian functions (Lee et al. 1996, Topilko et al. 1998). Supporting this presumption, our findings report for the first time that EGR-1 overexpression induced the expression of LH-R transcripts in granulosa cells. However, it remains unknown whether this induction was followed by a mechanism similar to that observed for mouse LH-R expression in Leydig cells. The isolation of bovine LH-R gene promoter and its functional characterization should help unravel the molecular basis for the species-specific regulation of LH-R in granulosa cells. Further studies are needed to determine whether EGR-1 is directly involved in the regulation of genes implicated in the ovulatory process.

The present study is the first to report the influence of EGR-1 on the expression of genes involved in ovulation. Indeed, our preliminary findings revealed that overexpression of EGR-1 also increased the levels of mRNA for PGES, PGHS-2, and EP2, but not for P450arom and P450scc in granulosa cells. As the expression of PGHS-2 and EP2 is required for ovulation, at least in rodents, our data suggest the involvement of EGR-1 in the ovulatory process, playing an important role in prostaglandin biosynthesis pathway. Previous studies have reported that the binding of EGR-1 to two GC-rich boxes of the PGES promoter regulates the expression of rat PGES in non-ovarian cells (Naraba et al. 2002, Subbaramaiah et al. 2004). Since two GC-rich regions are also present within

Figure 6 Forskolin-dependent induction of EGR-1 and its overexpression effect on the expression of PGHS-2, PGES, EP2, LH-R, P450arom, and P450scc transcripts in primary granulosa cells. Granulosa cells were isolated from bovine preovulatory follicles, as described in Materials and methods, and cultured in the presence or absence of forskolin (FSK; $10 \mu \mathrm{M})$ for various times. After incubation, total RNA and protein extracts were prepared. RNA samples (100 ng) were analyzed for the content of EGR-1 and GAPDH mRNA by a semiquantitative RT-PCR/Southern blot, and representative results of EGR-1 and GAPDH mRNA signals are presented from one sample per time point (A). The intensity of EGR-1 was normalized with those of the $\mathrm{GAPDH}$, and results are presented as ratios of EGR-1 to GAPDH (B). Mean \pm S.E.M. ( $n=3$ independent experiments). Bars marked with an asterisk are significantly different from $0 \mathrm{~h}(P<0.05)$. (C) Protein samples (100 $\mu \mathrm{g} / \mathrm{lane})$ were analyzed by onedimensional SDS-PAGE and immunoblotting technique using rabbit polyclonal antibody against human EGR-1. Representative results are presented from one sample per time point $(n=3$ independent experiments). The number on the right is for the approximate size of the immunoreactive bovine EGR-1. (D) Granulosa cells, either controls (Control) or those transfected (EGR-1) with the vector expressing bovine EGR-1, were cultured in the absence $(-)$ or presence $(+)$ of forskolin (FSK; $10 \mu \mathrm{M})$ for $24 \mathrm{~h}$. After incubation, RNA extracts were prepared and used (100 ng sample per reaction) to analyze the content of bovine EGR-1, PGHS-2, PGES, EP2, LH-R, P450scc, P450arom, and GAPDH mRNA by RT-PCR, as described in Materials and methods. Representative results are presented from one sample per treatment ( $n=3$ independent experiments). Numbers on the right indicate the size of the PCR fragment. 
the bovine PGES promoter (our unpublished observation), this suggests that the increase of PGES mRNA by EGR-1 overexpression in granulosa cells may be mediated by a mechanism similar to that observed for rat PGES expression. Sequence analyses indicated that no EGR-1 sites are found within bovine PGHS-2, whereas the bovine EP2 promoter has not been cloned. Therefore, the increase in levels of PGHS-2 mRNA after EGR-1 overexpression in granulosa cells may be through mechanisms that implicate the interactions of EGR-1 with other cofactors. Interestingly, the follicular induction of PGHS-2 (Sirois 1994) and PGES (Filion $e t$ al. 2001 ) occurred (18 to $24 \mathrm{~h}$ post-hCG) much later than those of EGR-1 ( $6 \mathrm{~h}$ post-hCG), thereby supporting the concept of the EGR-1 involvement in the increase of PGHS-2 and PGES mRNA in bovine preovulatory follicles. The characterization of their promoter activities should help to clarify this contention. Previous studies have shown that bovine granulosa cells isolated from small follicles express mRNA for P450arom and P450scc in cultures, which were stimulated by FSH (Sahmi et al. 2004). Similarly, our data also indicated that treatment with forskolin increases P450arom and P450scc mRNA abundance in primary granulosa cells, similar to that observed in differentiating follicles in vivo (Xu et al. 1995; Bao et al. 1997), suggesting the maintenance of granulosa cells in a non-luteinizing state. This state appeared unaffected by EGR-1 overexpression, since levels of $\mathrm{P} 450$ arom and $\mathrm{P} 450 \mathrm{scc}$ mRNA remained unchanged when compared to untransfected cells. This suggested a direct effect of EGR-1 on the expression of genes in granulosa cells, but not by a change in differentiation status of the cells, thereby strengthening the role of EGR-1 in the ovulatory process.

Studies on the molecular control of EGR-1 induction have been limited to rodents. In this species, interactions of EGR-1, in association with Sp1, with the proximal GC box within its promoter, and together with CREB and serum response factor have been shown to play a critical role in the induction of EGR-1 and its promoter activity in granulosa cells (Russell et al. 2003). Treatment with PGE2 has been suggested to regulate EGR-1 synthesis in non-ovarian cells (Danesch et al. 1994, Fujino et al. 2003, Faour et al. 2005), whereas the administration of an ovulation-inhibiting dose of indomethacin (an inhibitor of PGHS, which significantly reduces ovarian prostanoid production) did not alter EGR-1 expression during the early stage of the ovulatory process (Espey et al. 2000). This suggests that the pronounced increase of PGE2 in follicular fluid observed prior to ovulation is not involved in EGR-1 synthesis in preovulatory follicles. Moreover, this increase occurred much later than that of EGR-1 $(4 \mathrm{~h}$ post-hCG in rodents (Espey et al. 2000) and $6 \mathrm{~h}$ posthCG in cattle observed from this study), which thereby does not support the role of PGE2 in the increase of EGR-1 expression.

In summary, this study is the first to report the bovine EGR-1 cDNA and its gonadotropin-dependent regulation in preovulatory follicles of large monoovulatory species prior to ovulation. Levels of EGR-1 were high in granulosa cells, and low in theca cells after hCG treatment. Using primary granulosa cell cultures, we were able to replicate the regulation of EGR-1 as observed in vivo. Interestingly, overexpression of EGR-1 stimulated transcript expression of PGHS-2, PGES, EP2, and LH-R in these cultures, suggesting a potential involvement of EGR-1 in the ovulatory process, including prostaglandin biosynthesis pathway. Further investigation will be needed to study the molecular mechanisms behind the gonadotropin induction of EGR-1 and its stimulating effect on the other genes expressed during the important physiological process.

\section{Acknowledgements}

The authors would like to thank Danielle Rannou for her technical help with the immunohistochemistry and ovary collection from the slaughterhouse, and Drs Alan K Goff and Bruce Murphy for their constructive review of the manuscript. The authors declare that there is no conflict of interest that would prejudice the impartiality of this scientific work.

\section{Funding}

Canadian Institutes of Health Research (CIHR) Grant MT-13190 (to J S) supported this work. The nucleotide sequence reported in this paper has been submitted to GenBank/EBI Data Bank with accession number AY924307.

\section{References}

Abdel-Latif MM, Windle HJ, Fitzgerald KA, Ang YS, Eidhin DN, Li-Weber M, Sabra K \& Kelleher D 1999 Characterization of CD44 induction by IL-1: a critical role for Egr-1. Journal of Immunology 162 4920-4927.

Aicher WK, Alexander D, Haas C, Kuchen S, Pagenstecher A, Gay S, Peter HH \& Eibel H 2003 Transcription factor early growth response 1 activity up-regulates expression of tissue inhibitor of metalloproteinase 1 in human synovial fibroblasts. Arthritis and Rheumatism 48 348-359.

Alfonso-Jaume MA, Mahimkar R \& Lovett DH 2004 Co-operative interactions between NFAT (nuclear factor of activated T cells) c1 and the zinc finger transcription factors Sp1/Sp3 and Egr-1 regulate MT1-MMP (membrane type 1 matrix metalloproteinase) transcription by glomerular mesangial cells. Biochemical Journal $\mathbf{3 8 0}$ $735-747$.

Armstrong DT 1981 Prostaglandins and follicular functions. Journal of Reproduction and Fertility 62 283-291. 
Bao B, Garverick HA, Smith GW, Smith MF, Salfen BE \& Youngquist RS 1997 Changes in messenger ribonucleic acid encoding luteinizing hormone receptor, cytochrome P450-side chain cleavage, and aromatase are associated with recruitment and selection of bovine ovarian follicles. Biology of Reproduction 56 1158-1168.

Baron V, De Gregorio G, Krones-Herzig A, Virolle T, Calogero A, Urcis R \& Mercola D 2003 Inhibition of Egr-1 expression reverses transformation of prostate cancer cells in vitro and in vivo. Oncogene 22 4194-4204.

Bradford MM 1976 A rapid and sensitive method for the quantitation of microgram quantities of protein utilizing the principle of protein-dye binding. Analytical Biochemistry 72 248-254.

Brûlé S, Faure R, Doré M, Silversides DW \& Lussier JG 2003 Immunolocalization of vacuolar system-associated protein-60 (VASAP-60). Histochemistry and Cell Biology 119 371-381.

Call GB \& Wolfe MW 2002 Species differences in GnRH activation of the LHbeta promoter: role of Egr1 and Sp1. Molecular and Cellular Endocrinology 189 85-96.

Cao XM, Koski RA, Gashler A, McKiernan M, Morris CF, Gaffney R, Hay RV \& Sukhatme VP 1990 Identification and characterization of the Egr-1 gene product, a DNA-binding zinc finger protein induced by differentiation and growth signals. Molecular and Cellular Biology 10 1931-1939.

Chen L, Zhang H, Powers RW, Russell PT \& Larsen WJ 1996 Covalent linkage between proteins of the inter-alpha-inhibitor family and hyaluronic acid is mediated by a factor produced by granulosa cells. Journal of Biological Chemistry 271 19409-19414.

Cheng S, Afif H, Martel-Pelletier J, Pelletier JP, Li X, Farrajota K, Lavigne M \& Fahmi H 2004 Activation of peroxisome proliferatoractivated receptor gamma inhibits interleukin-1beta-induced membrane-associated prostaglandin E2 synthase-1 expression in human synovial fibroblasts by interfering with Egr-1. Journal of Biological Chemistry 279 22057-22065.

Danesch U, Weber PC \& Sellmayer A 1994 Arachidonic acid increases c-fos and Egr-1 mRNA in 3T3 fibroblasts by formation of prostaglandin E2 and activation of protein kinase C. Journal of Biological Chemistry 269 27258-27263.

Eid MA, Kumar MV, Iczkowski KA, Bostwick DG \& Tindall DJ 1998 Expression of early growth response genes in human prostate cancer. Cancer Research 58 2461-2468.

Espey LL 1980 Ovulation as an inflammatory reaction-a hypothesis. Biology of Reproduction 22 73-106.

Espey LL, Ujioka T, Russell DL, Skelsey M, Vladu B, Robker RL, Okamura H \& Richards JS 2000 Induction of early growth response protein-1 gene expression in the rat ovary in response to an ovulatory dose of human chorionic gonadotropin. Endocrinology $1412385-2391$.

Faour WH, Alaaeddine N, Mancini A, He QW, Jovanovic D \& Di Battista JA 2005 Early growth response factor-1 mediates prostaglandin E2-dependent transcriptional suppression of cytokineinduced tumor necrosis factor-alpha gene expression in human macrophages and rheumatoid arthritis-affected synovial fibroblasts. Journal of Biological Chemistry 280 9536-9546.

Filion F, Bouchard N, Goff AK, Lussier JG \& Sirois J 2001 Molecular cloning and induction of bovine prostaglandin $\mathrm{E}$ synthase by gonadotropins in ovarian follicles prior to ovulation in vivo. Journal of Biological Chemistry 276 34323-34330.

Fitzgerald KA \& O'Neill LA 1999 Characterization of CD44 induction by IL-1: a critical role for Egr-1. Journal of Immunology 162 $4920-4927$.

Fujino H, Xu W \& Regan JW 2003 Prostaglandin E2 induced functional expression of early growth response factor-1 by EP4, but not EP2, prostanoid receptors via the phosphatidylinositol 3-kinase and extracellular signal-regulated kinases. Journal of Biological Chemistry 278 12151-12156.

Gashler A \& Sukhatme VP 1995 Early growth response protein 1 (Egr-1): prototype of a zinc-finger family of transcription factors. Progress in Nucleic Acid Research and Molecular Biology 50 191-224.
Giri RK, Rajagopal V, Shahi S, Zlokovic BV \& Kalra VK 2005 Mechanism of amyloid peptide induced CCR5 expression in monocytes and its inhibition by siRNA for Egr-1. American Journal of Physiology Cell Physiology 289 C264-C276.

Goldhar AS, Vonderhaar BK, Trott JF \& Hovey RC 2005 Prolactininduced expression of vascular endothelial growth factor via Egr-1. Molecular and Cellular Endocrinology 232 9-19.

Haas TL, Stitelman D, Davis SJ, Apte SS \& Madri JA 1999 Egr-1 mediates extracellular matrix-driven transcription of membrane type 1 matrix metalloproteinase in endothelium. Journal of Biological Chemistry 274 22679-22685.

Halvorson LM, Ito M, Jameson JL \& Chin WW 1998 Steroidogenic factor- 1 and early growth response protein 1 act through two composite DNA binding sites to regulate luteinizing hormone beta-subunit gene expression. Journal of Biological Chemistry 273 14712-14720.

Huang RP, Darland T, Okamura D, Mercola D \& Adamson ED 1994 Suppression of v-sis-dependent transformation by the transcription factor, Egr-1. Oncogene 9 1367-1377.

Kaiser UB, Halvorson LM \& Chen MT 2000 Sp1, steroidogenic factor 1 (SF-1), and early growth response protein 1 (egr-1) binding sites form a tripartite gonadotropin-releasing hormone response element in the rat luteinizing hormone-beta gene promoter: an integral role for SF-1. Molecular Endocrinology 14 $1235-1245$.

Kimura N, Konno Y, Miyoshi K, Matsumoto H \& Sato E 2002 Expression of hyaluronan synthases and CD44 messenger RNAs in porcine cumulus-oocyte complexes during in vitro maturation. Biology of Reproduction 66 707-717.

Lee SL, Sadovsky Y, Swirnoff AH, Polish JA, Goda P, Gavrilina G \& Milbrandt J 1996 Luteinizing hormone deficiency and female infertility in mice lacking the transcription factor NGFI-A (Egr-1). Science 273 1219-1221.

Leung-Theung-Long S, Roulet E, Clerc P, Escrieut C, MarchalVictorion S, Ritz-Laser B, Philippe J, Pradayrol L, Seva C, Fourmy D et al. 2005 Essential interaction of Egr-1 at an islet-specific response element for basal and gastrin-dependent glucagon gene transactivation in pancreatic alpha-cells. Journal of Biological Chemistry $2807976-7984$.

Liu C, Adamson E \& Mercola D 1996 Transcription factor EGR-1 suppresses the growth and transformation of human HT-1080 fibrosarcoma cells by induction of transforming growth factor beta 1. PNAS 93 11831-11836.

Liu J, Carriere PD, Dore M \& Sirois J 1997 Prostaglandin G/H synthase-2 is expressed in bovine preovulatory follicles after the endogenous surge of luteinizing hormone. Biology of Reproduction 57 1524-1531.

Liu J, Antaya M, Boerboom D, Lussier JG, Silversides DW \& Sirois J 1999 The delayed activation of the prostaglandin G/H synthase-2 promoter in bovine granulosa cells is associated with downregulation of truncated upstream stimulatory factor-2. Journal of Biological Chemistry 274 35037-35045.

Maltzman JS, Carman JA \& Monroe JG 1996 Role of EGR1 in regulation of stimulus-dependent CD44 transcription in B lymphocytes. Molecular and Cellular Biology 16 2283-2294.

Milbrandt J 1987 A nerve growth factor-induced gene encodes a possible transcriptional regulatory factor. Science 238 797-799.

Mishra JP, Mishra S, Gee K \& Kumar A 2005 Differential involvement of calmodulin-dependent protein kinase II-activated AP-1 and c-Jun N-terminal kinase-activated EGR-1 signaling pathways in tumor necrosis factor-alpha and lipopolysaccharide-induced CD44 expression in human monocytic cells. Journal of Biological Chemistry 280 26825-26837.

Murdoch WJ, Hansen TR \& McPherson LA 1993 A review-role of eicosanoids in vertebrate ovulation. Prostaglandins 46 85-115.

Naraba H, Yokoyama C, Tago N, Murakami M, Kudo I, Fueki M, Oh-Ishi S \& Tanabe T 2002 Transcriptional regulation of the 
membrane-associated prostaglandin E2 synthase gene. Essential role of the transcription factor Egr-1. Journal of Biological Chemistry 277 28601-28608.

Richards JS, Russell DL, Ochsner S \& Espey LL 2002 Ovulation: new dimensions and new regulators of the inflammatory-like response. Annual Review of Physiology 64 69-92.

Russell DL, Doyle KM, Gonzales-Robayna I, Pipaon C \& Richards JS 2003 Egr-1 induction in rat granulosa cells by follicle-stimulating hormone and luteinizing hormone: combinatorial regulation by transcription factors cyclic adenosine $3^{\prime}, 5^{\prime}$-monophosphate regulatory element binding protein, serum response factor, sp1, and early growth response factor-1. Molecular Endocrinology 17 $520-533$.

Sahmi M, Nicola ES, Silva JM \& Price CA 2004 Expression of $17 \beta$ - and $3 \beta$-hydroxysteroid dehydrogenases and steroidogenic acute regulatory protein in non-luteinizing bovine granulosa cells in vitro. Molecular and Cellular Endocrinology 223 43-54.

Sayasith K, Bouchard N, Sawadogo M, Lussier JG \& Sirois J 2004 Molecular characterization and role of bovine upstream stimulatory factor 1 and 2 in the regulation of the prostaglandin $\mathrm{G} / \mathrm{H}$ synthase2 promoter in granulosa cells. Journal of Biological Chemistry 279 6327-6336.

Sirois J 1994 Induction of prostaglandin endoperoxide synthase-2 by human chorionic gonadotropin in bovine preovulatory follicles in vivo. Endocrinology 135 841-848.

Sirois J, Derek B \& Sayasith K 2004 Prostaglandin biosynthesis and action in the ovary. In The Ovary, 2nd edn, pp 233-247. Eds PCK Leung \& EY Adashi. New York: Elsevier Academic Press.

Sriraman V \& Richards JS 2004 Cathepsin L gene expression and promoter activation in rodent granulosa cells. Endocrinology 145 582-591.

Subbaramaiah K, Yoshimatsu K, Scherl E, Das KM, Glazier KD, Golijanin D, Soslow RA, Tanabe T, Naraba H \& Dannenberg AJ 2004 Microsomal prostaglandin E synthase-1 is overexpressed in inflammatory bowel disease. Evidence for involvement of the transcription factor Egr-1. Journal of Biological Chemistry 279 12647-12658.

Thiel G \& Cibelli G 2002 Regulation of life and death by zinc finger transcription factor Egr-1. Journal of Cellular Physiology 192 287-292.

Topilko P, Schneider-Maunoury S, Levi G, Trembleau A, Gourdji D, Driancourt MA, Rao CV \& Charnay P 1998 Multiple pituitary and ovarian defects in Krox-24 (NGFI-A, Egr-1)-targeted mice. Molecular Endocrinology 12 107-122.

Tsai SJ, Wiltbank MC \& Bodensteiner KJ 1996 Distinct mechanisms regulate induction of messenger ribonucleic acid for prostaglandin (PG) G/H synthase-2, PGE (EP3) receptor, and PGF2 alpha receptor in bovine preovulatory follicles. Endocrinology 137 3348-3355.

Xu ZZ, Garverick HA, Smith GW, Smith MF, Hamilton SA \& Youngquist RS 1995 Expression of messenger ribonucleic encoding cytochrome P450-side chain cleavage, cytochrome P45017 $\alpha$ hydroxylase, and cytochrome $\mathrm{P} 450$ aromatase are in bovine follicles during the first wave. Endocrinology 136 981-989.

Yan SF, Mackman N, Kisiel W, Stern DM \& Pinsky DJ 1999 Hypoxia/Hypoxemia-induced activation of the procoagulant pathways and the pathogenesis of ischemia-associated thrombosis. Arteriosclerosis, Thrombosis and Vascular Biology 19 2029-2035.

Yokoo M, Miyahayashi Y, Naganuma T, Kimura N, Sasada H \& Sato E 2002 Identification of hyaluronic acid-binding proteins and their expressions in porcine cumulus-oocyte complexes during in vitro maturation. Biology of Reproduction 67 1165-1171.

Yoshino M, Mizutani T, Yamada K, Tsuchiya M, Minegishi T, Yazawa T, Kawata H, Sekiguchi T, Kajitani T \& Miyamoto K 2002 Early growth response gene-1 regulates the expression of the rat luteinizing hormone receptor gene. Biology of Reproduction 66 1813-1819.

Received in final form 18 May 2006

Accepted 8 June 2006 